\author{
心房内血流転換を併施し心内修復術を行った内臓錯位 \\ 症候群・左側相同，鏡像型右胸心，完全型房室中隔欠損， \\ 単心房，下大静脈欠損，両側上大静脈の一例 \\ 加藤 伸康 $^{1)}$, 武田 充人 ${ }^{2)}$, 新井 洋輔 ${ }^{1)}$, 八田 英一郎 ${ }^{3)}$,

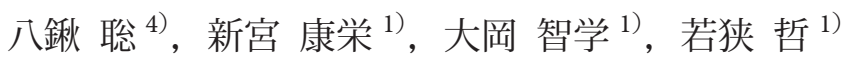 \\ ${ }^{1)}$ 北海道大学大学院医学研究院循環器呼吸器外科 \\ 2) 北海道大学大学院医学研究院小児科 \\ 3) 手稻溪仁会病院心臟血管外科 \\ 4) 帯広厚生病院小児科
}

\title{
Intra-Atrial Rerouting of Anomalous Systemic Venous Connection and Septation of Common Atrium in Intracardiac Repair of Complete Atrioventricular Septal Defect with Left Isomerism and Dextrocardia: A Case Report
}

\author{
Nobuyasu Kato ${ }^{1)}$, Atsuhito Takeda ${ }^{2)}$, Yosuke Arai ${ }^{1)}$, Eiichiro Hatta ${ }^{3)}$, \\ Satoshi Yakuwa ${ }^{4)}$, Yasushige Shingu ${ }^{1)}$, Tomonori Ooka ${ }^{1)}$, and Satoru Wakasa ${ }^{1)}$ \\ 1) Department of Cardiovascular and Thoracic Surgery, Hokkaido University Graduate School of Medicine, Hokkaido, Japan \\ ${ }^{2)}$ Department of Pediatrics, Hokkaido University Graduate School of Medicine, Hokkaido, Japan \\ 3) Department of Cardiovascular Surgery, Teine Keijinkai Hospital, Hokkaido, Japan \\ ${ }^{4)}$ Department of Pediatrics, Obihiro Kosei Hospital, Hokkaido, Japan
}

Left isomerism is frequently associated with anomalous systemic venous connection and common atrium, requiring systemic venous abnormality correction and common-atrium septation in biventricular repair. Our case was a 4-year-old girl diagnosed with left isomerism, dextrocardia, complete atrioventricular septal defect, common atrium, bilateral superior vena cava, and interruption of the inferior vena cava with hemiazygos vein connection. She underwent intracardiac repair with intra-atrial rerouting. Preoperative computed tomography suggested that extracardiac reconstruction of the anomalous systemic vein was inappropriate, and showed that all the pulmonary veins drain to the common chamber in the common atrium. Thus, the blood flow from the right superior vena cava was diverted into the left side of the common atrium through an intra-atrial tunnel. Complete atrioventricular septal defect was repaired with modified one-patch method, and the patch divided the common atrium into the right and left atria. She was discharged on postoperative day 11 without obstruction in systemic and pulmonary venous return. Therefore, if all the pulmonary veins drain to the common chamber, intra-atrial rerouting may effectively correct anomalous systemic venous connection in the septation of the common atrium.

Keywords: congenital heart disease, anomalous systemic venous connection, common atrium, left isomerism, complete atrioventricular septal defect

2020 年 8 月 25 日受付, 2020 年 11 月 23 日受理

著者連絡先：干060-8638 北海道札幌市北区北 15 条西 7 丁目 北海道大学大学院医学研究院循環器呼吸器外科 加藤伸康 doi: $10.9794 /$ jspccs.37.126 
内臟錯位症候群・左側相同に関連する心疾患では下大静脈欠損や両側上大静脈などの体静脈還流異常 や単心房を合併することも多く，二心室修復の際には体静脈の再建も要する．今回我々は，内臓錯位 症候群 - 左側相同, 鏡像型右胸心, 房室中隔欠損, 単心房, 両側上大静脈, 下大静脈欠損, 半奇静脈 接続の 4 歳女児に対し, 心房内血流転換を含めた心内修復術を行った。術前 CT では体静脈の心外再建 には不向きな心大血管形態で, 共通肺静脈腔の存在から心房内血流転換が適していると判断し, 右上 大静脈の血流を左側心房へ心房内血流転換しつつ, 房室中隔欠損に対して modified one patch 法で共 通房室弁の分割と心房中隔作成を行った。術後検査では体静脈や肺静脈の狭窄は認めず, 経過良好で 11 日目に自宅退院となった. 共通肺静脈腔を呈している場合は, 心房内血流転換は体静脈還流異常に 対して有用な術式となりうる.

\section{はじめに}

内臓錯位症候群・左側相同に合併する心疾患には二 心室修復が可能な心形態である場合が存在するが，下 大静脈欠損, 両側上大静脈などの体静脈還流異常や単 心房を合併することもあり, 心内修復に際し体静脈へ の介入を必要とする．体静脈還流異常に対する介入方 法としては, 単純結禁や心内もしくは心外再建の報告 がある. 心外再建として両側上大静脈に対して解剖学 的修復や心耳との吻合による報告があるが, 解剖学的 修復では静脈間の距離や血管径が重要で周囲構造物と の解剖学的な制約があり, 心耳との吻合は比較的手技 は容易だが心臟前面を通すため再開胸時に損傷のリス クとなる.心内再建は上大静脈の還流異常だけではな く下大静脈欠損なども含めた体静脈還流異常の多くの 症例に適応できる可能性があるが，心房内での縫合ラ インが複雑となるため手術手技の難易度が上がる。再 建方法には一定の見解はなく, 個々の症例ごとに介入 方法を検討する必要がある.

今回, 両側上大静脈, 下大静脈欠損, 単心房を合併 した内臓錯位症候群 - 左側相同, 鏡像型右胸心, 完全 型房室中隔欠損症の症例に対して，心房内血流転換を 含めた心内修復術を行い良好な結果を得た. 本症例で は肺静脈還流異常を伴わずに肺静脈が共通肺静脈腔を 形成しており, 比較的シンプルな縫合ラインで肺静 脈・体静脈還流に障害を来すことなく心房内血流転換 が可能であった. 体静脈還流異常に対する術式を検討 する際に, 共通肺静脈腔の存在は判断材料の一つにな ると考えられ，本症例に関して報告する。

\section{症例}

症例 $: 4$ 歳女児

診断：内臟錯位症候群 - 左側相同, 多脾症, 鏡像型右 胸心, 完全型房室中隔欠損症, 右側大動脈弓, 半奇静 脈接続を伴う下大静脈欠損, 両側上大静脈, 単心房,
中等度肺動脈弁狭窄

現病歴：胎览診断症例で, 在胎 40 週 3 日, 体重 $3,380 \mathrm{~g}$ で仮死なく出生し，精査で上記診断となった。洞機能 不全に伴う軽度徐脈を認めたが，心不全症状なく自然 軽快した。 心室中隔欠損孔は非常に小さく, 新生児・ 乳児早期の介入は不要と判断され日齢 9 で自宅退院 し，外来で経過観察となった。 心室条件からは二心室 修復が可能だったが，体静脈還流異常に対して複雑な 心房内操作を要することから体重増加を待ち心内修復 の方針となった．途中経過で心室中隔欠損は自然閉鎖 し，著明なチアノーゼ増悪や心不全増悪のイベントな く BNP は 40〜 $100 \mathrm{pg} / \mathrm{mL}$ で経過し，4歳で根治手術 目的に当院紹介となった.

入院時現症: 身長 $99 \mathrm{~cm}$, 体重 $14.6 \mathrm{~kg}$, 心拍数 72 回 /分, 血圧 83/51 mmHg, $\mathrm{SpO}_{2}=82 \%$, 肺音 清明，心 音 整，胸骨右縁第三肋間に Lev3/6 沉収縮期雑音聴 取, 腹部 平坦・軟，肝を左側上腹部に触知，四肢冷 感はなくチアノーゼを認めた.

入院時血液検査：Hb $15.0 \mathrm{~g} / \mathrm{dL}, \mathrm{Hct} 45 \%$, T-Bil $0.9 \mathrm{mg} /$ $\mathrm{dL}$, AST $30 \mathrm{U} / \mathrm{L}$, ALT $18 \mathrm{U} / \mathrm{L}$, BUN $13 \mathrm{mg} / \mathrm{dL}, \mathrm{Cr}$ $0.39 \mathrm{mg} / \mathrm{dL}, \mathrm{BNP} 103.1 \mathrm{pg} / \mathrm{mL}$.

心電図：洞機能不全のため洞調律と接合部調律が混 在, PQ 0.16, QRS 0.08, QRS 軸 $-60^{\circ}$

心エコー：心血管区分法では $\{\mathrm{A}(\mathrm{I}), \mathrm{L}, \mathrm{IN}\}$ の右側大 動脈弓を伴う鏡像型右胸心, 完全型房室中隔欠損で あった。 心房形態は単心房で，心房中隔壁は認めな かった. 半奇静脈接続を伴う下大静脈欠損で, 両側の 上大静脈と肝静脈抢よび 4 本の肺静脈が単心房へと還 流していた。膜様組織により心室中隔欠損は閉鎖して いた。共通房室弁逆流は右側（左室側）が軽度，左側 （右室側）も軽度のみであった。中等度の肺動脈弁狭 窄（流速 $3.7 \mathrm{~m} / \mathrm{s}$ ） があり, 肺動脈弁は三尖で癒合に よる解放制限を認めた。

造影 CT (Fig. 1)：鏡像型右胸心，単心房，右側大動 脈弓を認めた。両側の上大静脈は単心房の左右頭側へ それぞれ接続し，下大静脈欠損で下肢の静脈血流は半 

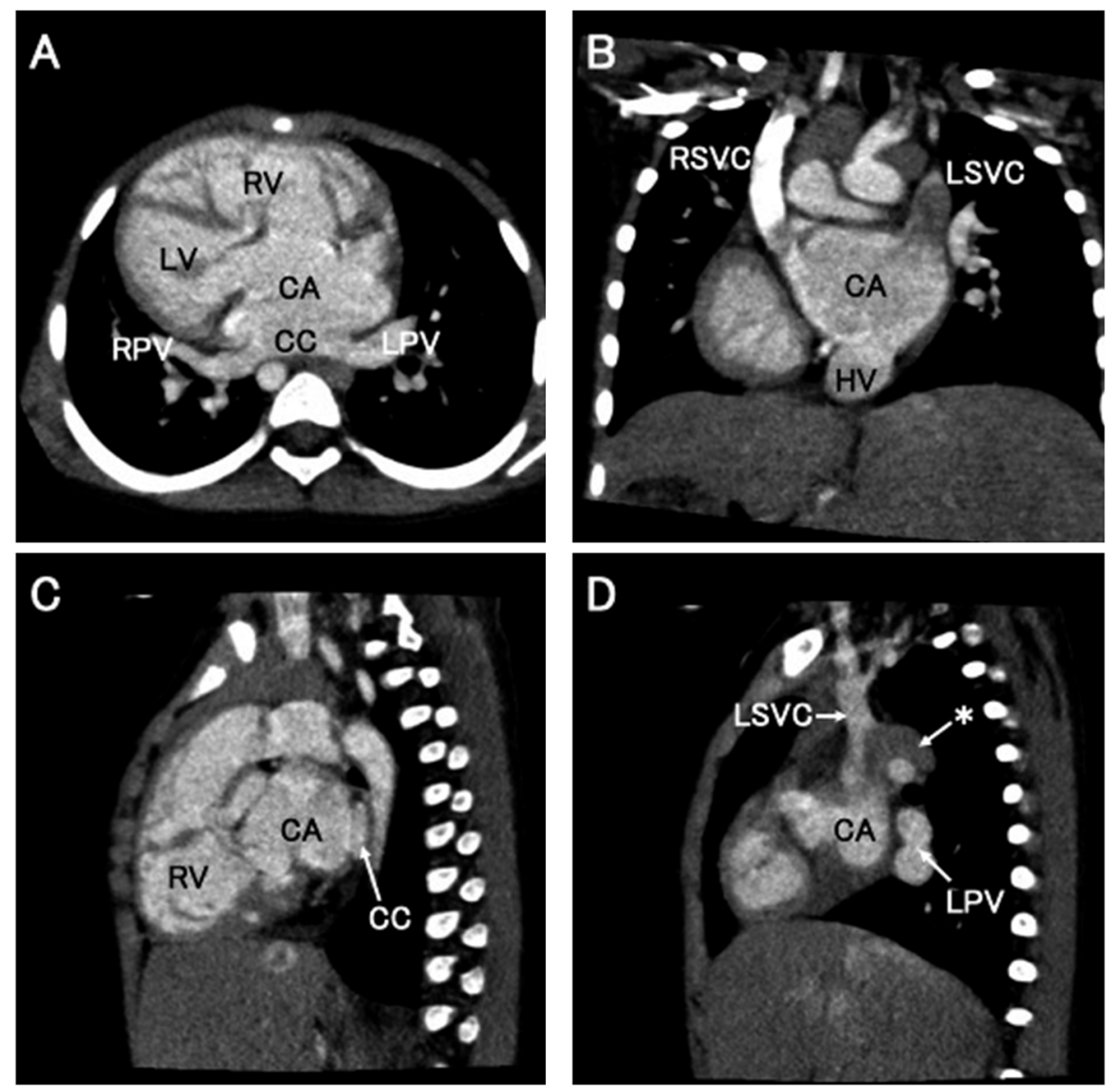

Fig. 1 Preoperative CT images

Patient's cardiac anatomy presented in the axial view (A), coronal view (B), sagittal view (C and D). Asterisk shows hemiazygos connection. CA, common atrium; CC, common chamber; CT, computed tomography; HV, hepatic vein; LPV, left pulmonary vein; LSVC, left superior vena cava; RPV, right pulmonary vein; RSVC, right superior vena cava.

奇静脈を介して左上大静脈へ接続, 肝静脈は単心房の 尾側中央に接続, 肺静脈は上下左右四本が共通肺静脈 腔を形成して単心房の背側中央に合流していた。 右室 流出路および肺動脈弁上や未梢肺動脈に狭窄は認めな かった. 腹部臟器も逆位であり, 右側に胃, 左側に肝 臓が位置していた。

総合所見

内臟錯位症候群・左側相同に合併した鏡像型右胸 心, 完全型房室中隔欠損症, 単心房, 両側上大静脈, 半奇静脈接続を伴う下大静脈欠損, 肺動脈弁狭窄の症 例. 房室中隔欠損に対しては心室中隔欠損が閉鎖して いることから modified one patch 法による修復, 体 静脈還流異常を伴う単心房に対しては肺静脈が共通肺 静脈腔を呈していることから心房内血流転換を含めた 心房中隔壁作成, 肺動脈弁狭窄に対しては交連切開の 方針とした. 洞機能不全に関してはこれまでの経過で 明らかな徐脈は認めておらず，手術の時点ではペース
メーカー植え込みの適応はないと判断し，周術期は必 要に応じて一時ペーシングリードで管理する方針とし た.

\section{手術所見}

胸骨正中切開で開胸し心形態を観察すると，左前に 右室，右後ろに左室の逆位となっている鏡像型右胸心 であり，大動脈は右側大動脈弓，心耳形態は両側左心 耳であることが確認できた（Fig. 2A，B）。動脈管結禁 の後に上行大動脈送血, 左右上大静脈と肝静脈の三本 脱血で人工心肺確立し, 大動脈遮断・ 心停止とした. 心停止の直前に，術者の立ち位置を左に変更した．左 側心房（右房）を切開し内部を観察したところ，房室 弁は共通前尖と共通後尖の間には連続した弁組織を認 めない共通房室弁形態だが，心室中隔欠損は膜様閉 鎖しており交通孔は認めなかった（Fig. 2C)。心房は 中隔壁の痕跡を認めず単心房形態で, 背側に肺静脈の 集まった共通肺静脈腔があり, 右頭側に右上大静脈の 

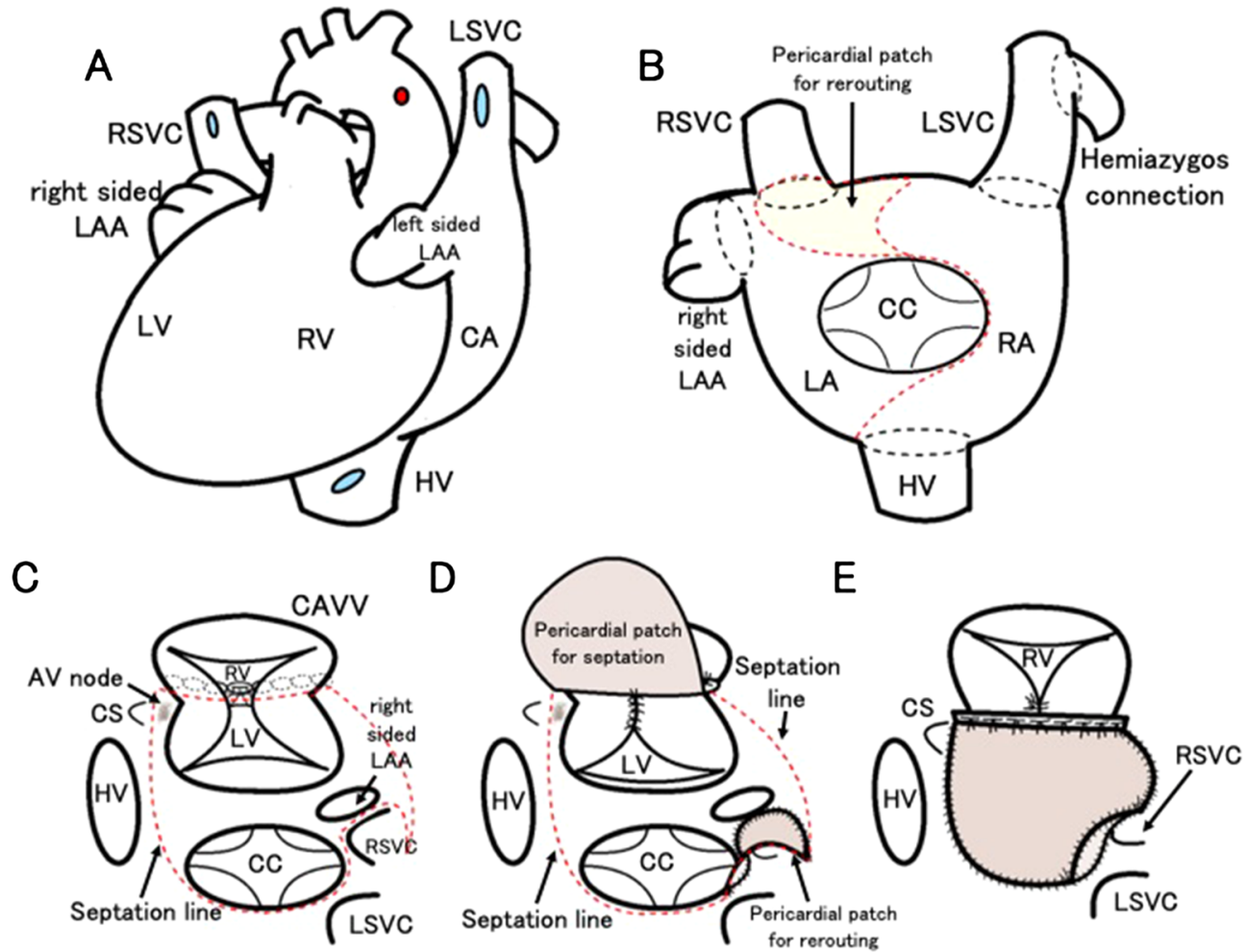

Fig. 2 Operative schema

(A) Anterior view of the heart. The arterial and venous cannulation sites are shown as red and blue dots, respectively. (B) Spatial relationships of systemic and pulmonary venous connections in the CA. (C-E) Intraatrial septation and rerouting of the CA in the surgeon's view from left side of the patient. The suture lines of intraatrial patch for rerouting and septation are presented by red dashed lines. AV, atrioventricular; CA, common atrium; CAVV, common atrioventricular valve; CC, common chamber; CS, coronary sinus; HV, hepatic vein; LA, left atrium; LAA, left atrial appendage; LSVC, left superior vena cava; LV, left ventricle; RA, right atrium; RSVC, right superior vena cava; RV, right ventricle.

開口部と右側左心耳, 尾側中央に肝静脈の開口部を認 めた．また冠静脈洞を共通房室弁の中央尾側に認め, そのやや房室弁寄りに房室結節と思われる構造を認め た．右上大静脈に対する血流転換のため，心房天井部 に自己心膜でトンネルを作成した（Fig. 2D）。房室中 隔欠損に対しては modified one patch 法での修復の方 針とし, 膜様閉鎖した心室中隔欠損部を補強しつつ共 通房室弁を左右に分け，心房中隔壁作成のための自己 心膜を縫着し，右側房室弁（左室側の房室弁）に対し ては Cleft 閉鎖し弁形成を施行した，共通房室弁を左 右に分離した自己心膜パッチを心房中隔壁として，房 室結節は右側心房 $($ 左房) へ, 冠静脈洞は左側心房 $($ 右 房）へ還流するように縫合ラインを設定した。心房中 隔パッチの頭側は右上大静脈の血流転換のための心膜 パッチと合わせて, 体静脈が左側心房（右房），肺静 脈が右側心房（左房）へと還流するように心房中隔壁 を作成（Fig. 2B，E）し，左側房室弁（右室側）の弁 形成を追加した。その後, 主肺動脈を切開し肺動脈弁 を観察，三尖だが交連の癒合が強く, 各々に交連切開
を施行した．左心系の空気抜きを十分に行い大動脈遮 断解除．接合部調律であったが，房室ブロックもなく 速やかに自己心拍再開し，心房切開線を閉鎖した. ペーシングリードを左側心房（右房）に留置，ドレー ン留置し型どおり閉胸閉創した。手術 5 時間 11 分, 人工心肺 3 時間 38 分, 大動脈遮断 2 時間 24 分で, 手術は無輸血で完遂した.

術後経過：術後出血もなく初日は心房ペーシング補助 で血行動態安定し，同日夜間に人工呼吸器離脱可能で あった. 中心静脈圧 8〜9 mmHg で安定していたため 翌日には心房ペーシングやカテコラミンを中止した。 自己脈は心拍数 80〜100 回/分程度の接合部調律で経 過し, 以後も高度の徐脈は認めなかった. 術後第 2 病 日に一般病棟へ転棟し，その後も順調に経過した。術 後心エコーでは両側房室弁逆流はいずれも軽度, 血 流転換した右上大静脈や肝静脈の血流は加速なくス ムーズに左側心房である右房に還流しており，右房 から右室または肺静脈から左室への流入血流障害も認 めなかった．CT 所見上も心房内血流転換や心房中隔 

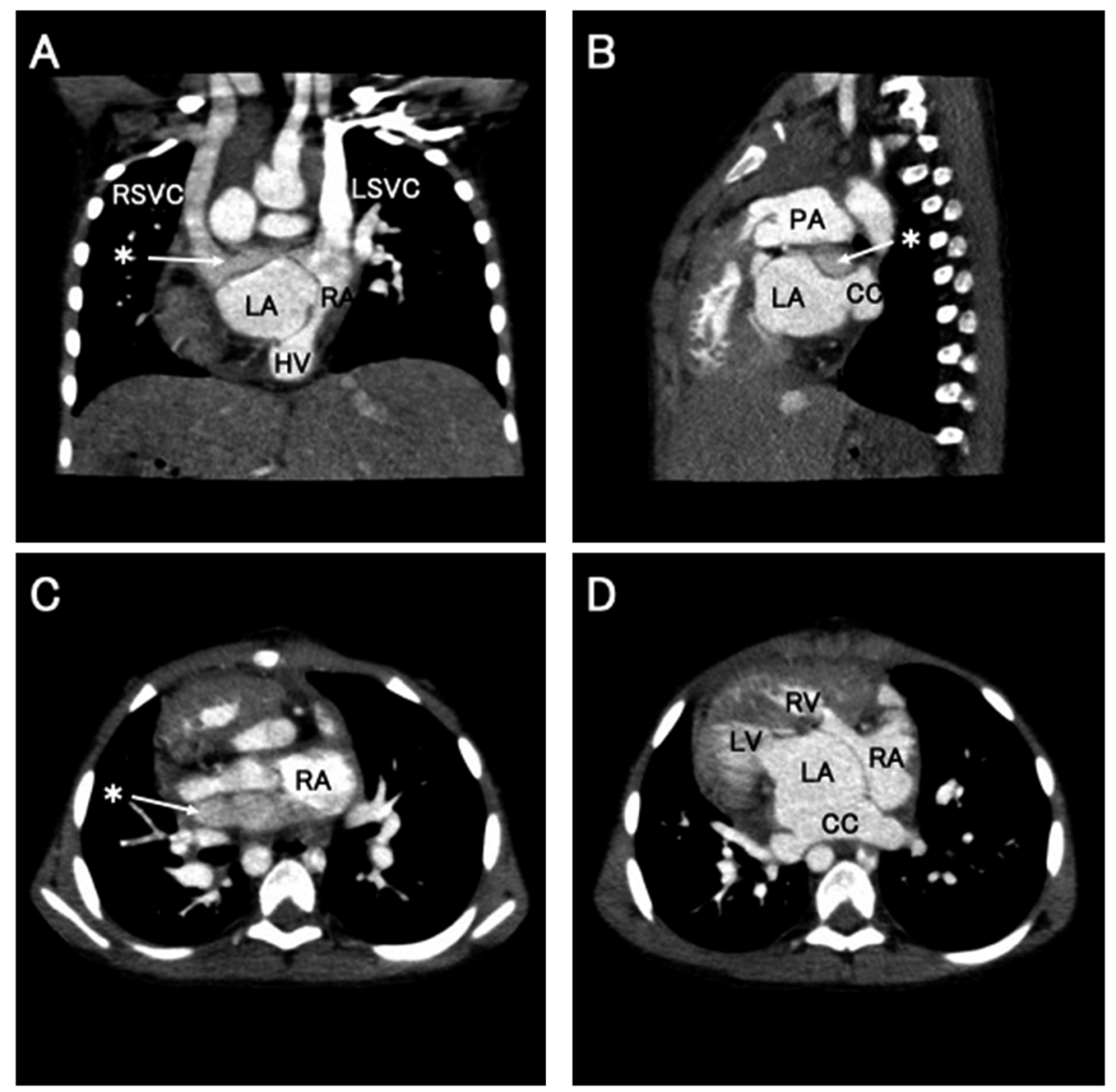

Fig. 3 Postoperative CT images

Postoperative cardiac morphology in the coronal view (A), sagittal view (B), and axial view (C, D). Asterisk shows intraatrial rerouting of RSVC. The CA is separated by pericardial patch without obstruction of pulmonary and systemic venous return (D). CC, common chamber; CT, computed tomography; HV, hepatic vein; LA, left atrium; LSVC, left superior vena cava; LV, left ventricle; PA, pulmonary artery; RA, right atrium; RSVC, right superior vena cava; RV, right ventricle.

形成に用いた心膜パッチの形態は問題なく（Fig. 3)， 体静脈還流路や肺静脈還流路に狭窄を認めず，術後第 11 病日に退院となった. 現在, 術後 1 年 4 か月経過 しているが，房室弁逆流増悪や静脈還流障害など認め ず，経過良好である。

\section{考察}

内臓錯位症候群は, 本来左右非対称に発達する胸腹 部臟器の左右分化障害（左右軸決定の障害）により, 各臓器に種々の先天異常が発生する症候群である. 個々の症例において胸腹部の各蔵器の位置や形態の診 断が必要となる。臟については, 内臓錯位症候群で は単心室症を合併することが多いが，右側相同と比較 して左側相同では二心室修復可能な心形態である場合 が多い ${ }^{1)}$. また, 多脾症が先天性心疾患に関連する肺
高血圧の早期増悪因子であるとの報告 ${ }^{2 ）}$ もあり，可 及的に二心室修復を目指すのが理想である。その一方 で左側相同では下大静脈久損（合併率 60〜95\%）や 上大静脈の接続異常 (合併率約 $60 \%$ ), 単心房を合併 することも多いため ${ }^{1)}$, 二心室修復の際には体静脈還 流異常に対する外科的介入が重要となる.

両側上大静脈に対しては，一方が明らかに低形成で あったり，無名静脈など十分な左右の交通がある場合 は単純結禁も考慮される。単純結紮の場合, 結禁した 上大静脈圧が 30〜 35 mmHg 以下であれば脳合併症な く治療可能との報告もあるが ${ }^{3,4)}$, 静脈圧上昇により脳 還流障害を来す可能性もあり ${ }^{5)}$, 可能な限り何らかの 形で再建すべきと考えている. 上大静脈還流異常に対 する再建方法としては心内再建法 ${ }^{4,6-8)}$ と心外再建法 4,8,9) が報告されているが，ほとんどの報告は通常心 形態における左房直接還流型の左上大静脈遺残症例に 
対してであり，鏡像型右胸心に対する報告は少ない。 重要なことは再建する上大静脈はもちろんのこと, 他 の体静脈・肺静脈の狭窄を来すことなく再建すること である．特に心内再建法においては，肺静脈開口部と 体静脈開口部の位置関係が静脈の還流障害を予防する うえで非常に重要である. 本症例では肺静脈還流異常 を伴わずに肺静脈は共通肺静脈腔を形成し, 術前 CT にて心房内・共通肺静脈腔の頭側に右上大静脈の径と ほぼ同程度の大きさの空間を認めていたことから, 体 静脈や肺静脈の血流障害を来すことなく右上大静脈の 心房内血流転換が可能であると考えられた. また，心 内修復として, 房室中隔欠損に対する共通房室弁の分 割と単心房に対する心房の中隔形成が必要であったこ とから, 自己心膜を用いて右上大静脈の心房内トンネ ル作成と共通房室房室弁の分割 - 心房中隔形成を同時 に行うことで, 体静脈還流異常と単心房を伴う房室中 隔欠損症に対して心内修復が可能になると判断した。 心房内血流転換の経路としては肺静脈と房室弁の間を 通す経路もあるが, 心房内の尾側を回る場合, 冠静脈 洞の環流障害や房室結節の障害を回避した縫合線を 必要とするため, それらの損傷のリスクがなくかつ最 短経路となる心房天井側の経路がより適していると判 断した. 解剖学的修復に関しても検討したが, 大動脈 周囲に十分なスペースがなく, 両上大静脈の距離がや や遠いことから不適と考えた. また, 大動脈基部前面 を通して再建する右上大静脈一心耳吻合については, 術前 CT にて心臓前面のスペースがそしく胸骨と心蔵 に挟まれて早期閉塞となる可能性が高いこと, 開存が 得られても今後再開胸が必要になった際に胸骨との癒 着から血管損傷のリスクとなり, 洞機能不全や房室弁 閉鎖不全の増悪などで複数回の開胸・開心術の可能性 が残る本症例においては避けるべきと判断した。 心房 内血流転換の問題として心房内の縫合ラインを起源と する術後の不整脈やパッチ使用に伴う心房内血栓があ るが，単心房を合併している場合は心房中隔形成のた めのパッチ縫着が必要となるため, 体静脈還流異常に 対して追加で心房内血流転換を行うことは不整脈や心 内血栓のリスク増加にはそれほどならないであろう。 また，本症例のように共通肺静脈腔が明らかな場合に は，心房内の縫合ラインがそれほど複雑にならずに心 房中隔形成に心房内血流転換を追加することが可能で あると考えており, 共通肺静脈腔の存在は術式選択の 際の一助となると考えている. もし心臓型の肺静脈還 流異常を伴う場合には, 心房内のパッチ縫合ラインが より複雑となるため, 解剖学的修復や心耳-上大静脈 の吻合などの心外再建法も考慮すべきだろう.
今回，パッチ・バッフルの素材として新鮮自己心膜 を使用したが，他にも処理自己心膜やゴアテックス パッチ/人工血管などが選択肢となりうる。ゴアテッ クスパッチやゴアテックス人工血管に関しては，パッ チや心内トンネルの形状・形態維持に優れている反 面, 抗血栓性では心膜より劣ると考えており, 静脈の 閉塞のリスクに加え，左房側に血栓が生じた場合は全 身の血栓塞栓症となる懸念があり，今後の成長と抗血 栓性の有用性の点から今回は自己心膜を選択した。心 膜の処理についてはグルタールアルデヒド処理があ り，パッチの強度上昇が得られる一方で遠隔期の石灰 化が懸念され，また低圧系への使用でもあり強度は未 処理の心膜でも十分と判断した. ただし術後の検査で は有意な静脈狭窄は認めないものの, 左房圧の方が高 いため, CT ではパッチが右心系へ凸となっている. 新鮮自己心膜を使用する際には, 房室弁逆流の残存程 度次第では心内の静脈路への圧迫も生じうるため, 注 意が必要である.

\section{結 語}

内臓錯位症候群・左側相同に合併した胸像型右胸 心，完全型房室中隔欠損，体静脈還流異常（両側上大 静脈, 下大静脈欠損, 半奇静脈接合) の症例に対し て，心房内血流転換を併施した心内修復を行い良好な 結果を得た。共通肺静脈腔の存在は, 体静脈還流異常 に対する術式選択の一助となりうる. 今後, 遠隔の フォローが重要である.

\section{倫理的配慮}

患者個人を特定しうる情報に関しては十分匿名化を行った。

\section{利益相反}

本論文において，開示すべき利益相反（COI）はない.

\section{著者の役割}

加藤伸康：診療（手術, 周術期管理), 論文原稿作成, データ 収集

武田充人：浐療（術前術後の各種検查など）, 論文指導・校閲 新井洋輔 : 診療 (手術, 周術期管理)

八田英一郎：診療 $($ 手術 $)$, 論文指導・校閲

八鍬 聡：診療 (術後検查), データ収集

新宮康栄 : 論文指導・校閲

大岡智学 : 論文指導・校閲

若狭 哲: 論文指導・校閲 


\section{引用文献}

1）山岸敬幸：ここまで知っておきたい発生学一左右軸の 決定と内蔵錯位症候群一. 日小児循環器会誌 2018; 34: 99-104

2) Shibata A, Mori H, Kodo K, et al: Polysplenia syndrome as a risk factor for early progression of pulmonary hypertension. Circ J 2019; 83: 831-836

3) Freed MD, Rosenthal A, Bernhard WF: Balloon occlusion of a persistent left superior vena cava in the preoperative evaluation of systemic venous return. J Thorac Cardiovasc Surg 1973; 65: 835-839

4) de Leval MR, Ritter DG, McGoon DC, et al: Anomalous systemic venous connection, surgical considerations. Mayo Clin Proc 1975; 50: 599-610

5) 山田 学, 藤井尚文, 宮沢総介, ほか：左房へ還流する 左上大静脈遺残症の血流処置一単純結紮術に関する考 察—. 日胸外会誌 1979; 27: 1448-1452
6) Komai H, Naito Y, Fujiwara K: Operative technique for persistent left superior vena cava draining into the left atrium. Ann Thorac Surg 1996; 62: 1188-1190

7) Ahmadi A, Mocellin R, Spillner G: Left atrial isomerism combined with right-sided heart, common atrium, incomplete atrioventricular septal defect and partial anomalous systemic and pulmonary venous drainage: Report of a case with successful surgical correction. Int J Cardiol 1988; 19: 378-381

8) Vargas FJ: Reconstructive methods for anomalous systemic venous return: Surgical management of persistent left superior vena cava. Semin Thorac Cardiovasc Surg Pediatr Card Surg Annu 2008; 11: 31-38

9) Erek E, Aydin S, Suzan D: Right atrial flap repair for left superior vena cava draining into left atrium. Thorac Cardiovasc Surg 2016; 64: 59-61 